\title{
KONFLIK KEPEMIMPINAN DALAM PEKABARAN INJIL: SEBUAH PEMAKNAAN TERHADAP PERSELISIHAN PAULUS DAN BARNABAS DALAM KISAH PARA RASUL 15:35-41
}

\author{
Dwi Atni Setyowati \\ Sekolah Tinggi Theologia Abdiel \\ dwiatni2@gmail.com
}

\begin{abstract}
This paper discusses a conflict involving Paul and Barnabas in Acts 15:35-41. Stott argued that this conflict is a sad story. Nevertheless, based on the narrative interpretation exploring some narrative components in Acts 15:3541, namely plot, time and place setting, characters, and narrative rhetoric, this paper is to show that the story of the conflict is not a sad story. Actually, the story is a part of Luke's rhetoric in exposing that the work of the Holy Spirit was not be able to be resisted by everything and telling about the consequences of different models of leadership especially in recruitment for the sake of God's mission as well.
\end{abstract}

Keywords: Paul, Barnabas, the Holy Spirit, leadership, narrative interpretation

\section{Pendahuluan}

Perselisihan merupakan hal yang biasa terjadi, termasuk dalam konteks persekutuan orang-orang beriman. Kerapkali persoalan muncul ketika perbedaan pandangan tidak dapat diperdamaikan. Masing-masing pihak berkeras pada pendiriannya sehingga menimbulkan perselisihan yang berakibat munculnya kelompok-kelompok baru. Situasi ini dapat membuat banyak orang beriman prihatin dan membayangkan andai saja gereja tidak pernah mengalami perpecahan; atau berharap gereja tetap dipersatukan dalam naungan organisasi atau lembaga yang tunggal. Pertanyaan reflektif yang bisa kita ajukan adalah apakah perselihan pasti bersifat buruk dan merusak? Apakah perselisihan harus dihindari seutuhnya? Apakah tidak ada makna apapun yang bersifat positif di balik perselisihan? Pertanyaan-pertanyaan tersebut telah mendorong orang-orang Kristen mencermati bagaimana perselisihan juga terjadi di tubuh gereja perdana. Perselisihan ini melibatkan tokoh-tokoh penting di dalamnya. Kita ambil contoh perselisihan antara Paulus dan Barnabas seperti diceritakan dalam Kisah Para Rasul 15:35-41. Berkenaan dengan teks tersebut John R.W. Stott memberikan komentarnya sebagai berikut: 
The single province of Syiria (to which Antioch belonged) and Cilicia (in which Tarsus was situated) had been the scene of some of Paul's earliest evangelistic endeavours (9:30). It evidently had some Gentile churches, for they are specifically named at the head of the Jerusalem letter (23). But before Luke can narrate how the letter reached them, he is obliged in his honesty to tell the sad story of how Paul and Barnabas to separate. ${ }^{1}$

Komentar Stott yang menyebut kisah perpisahan antara Paulus dan Barnabas sebagai sad story memperlihatkan pandangannya yang negatif terhadap perselisihan tersebut. Ia melihat bahwa keputusan Paulus dan Barnabas untuk mengambil arah yang berbeda dalam perjalanan pelayanan adalah sesuatu yang menyedihkan. ${ }^{2}$ Apakah tidak ada hal-hal positif di balik kisah perselisihan Paulus dan Barnabas tersebut? Apakah keputusan Paulus dan Barnabas untuk mengambil jalan dan arah yang berbeda benar-benar buruk? Dengan memanfaatkan hasil penafsiran terhadap unsur-unsur narasi dalam Kisah Para Rasul 15:35-41, penulis ingin memperlihatkan bahwa perselisihan antara Paulus dan Barnabas tidak dapat disebut sebagai kisah yang menyedihkan karena merupakan konsekuensi perbedaan dua pemimpin yang memiliki prinsip-prinsip kuat dalam menentukan orang-orang yang layak diajak bekerja sama untuk mencapai visi dan misi bersama. Kesimpulan ini didasarkan pada hasil penafsiran terhadap unsur-unsur narasi, khususnya plot, setting tempat dan waktu, penokohan atau karakter, serta retorika dalam penceritaan di Kisah Para Rasul 15:35-41 yang memperlihatkan bahwa kisah perselisihan antara Paulus dan Barnabas berfungsi untuk memperkuat gagasan mengenai pekerjaan Roh Kudus yang tidak dapat dihambat oleh siapapun, dan berperan dalam memulai kisah-kisah yang menampilkan dominasi tokoh Paulus.

\section{Roh Kudus di balik Karya Rasul-rasul}

Kisah Para Rasul 15:35-41 berisi cerita tentang situasi setelah keputusan persidangan antara Rasul-rasul dan para penatua (Kis. 15:1-29). Mereka membahas apakah orang-orang Kristen yang bukan Yahudi harus disunat menurut adat istiadat orang Yahudi. Dalam persidangan tersebut Paulus dan Barnabas diutus bersama beberapa orang jemaat dari Antiokhia untuk memberikan penjelasan, sekaligus memberi pertanggungjawaban atas penolakan Paulus terhadap pengajaran orang-orang dari Yudea yang menuntut setiap orang

\footnotetext{
${ }^{1}$ John R. W. Stott, The Message of Acts (Leicester: Inter-Varsity Press, 1990), 253.

${ }^{2}$ Pandangan Scott sejalan dengan Swindoll yang menyebutnya sebagai kisah yang paling menyedihkan. Charles R. Swindoll, The Growth of An Expanding Mission: A Study of Acts 10:1-18:18 (Anaheim, California: IFL, 1992), 126.
} 
Kristen mengikuti adat istiadat yang diwariskan oleh Musa. Mereka berpandangan bahwa jikalau orang-orang Kristen bukan Yahudi tidak disunat maka mereka tidak dapat diselamatkan.

Secara keseluruhan, Kisah Para Rasul menuturkan bagaimana Injil tersebar mulai dari Yerusalem hingga ke kota Roma, dan tersebar juga di antara orang-orang Yahudi maupun orang-orang bukan Yahudi. ${ }^{3}$ Walaupun bagian dari Perjanjian Baru ini disebut Kisah Para Rasul, tetapi peran utamanya adalah Roh Kudus. ${ }^{4}$ Roh Kudus berada dibalik keberhasilan para rasul dan orang-orang lainnya yang memberikan kesaksian tentang Injil sebagaimana disebutkan dalam Kisah Para Rasul 1:2. ${ }^{5}$ Di situ dinyatakan bahwa sebelum peristiwa kenaikan Yesus ke surga, Ia telah memberi perintah-Nya, mengirimkan Roh Kudus kepada rasul-rasul yang dipilih-Nya. Selain itu, dalam Kisah Para Rasul 1:8 dikatakan, "Tetapi kamu akan menerima kuasa, kalau Roh Kudus turun ke atas kamu, dan kamu akan menjadi saksi-Ku di Yerusalem dan di seluruh Yudea dan Samaria dan sampai ke ujung bumi." Kehadiran para rasul sendiri dalam keseluruhan kitab ini diwakili oleh oleh beberapa tokoh, di antaranya Petrus yang mulai ditampilkan dominan pada peristiwa turunnya Roh Kudus di hari Pentakosta (Kis. 2:14-40), kemudian dilanjutkan dengan kisah penyembuhan oleh Petrus terhadap orang lumpuh (Kis. 3:1-10), serta khotbah di serambi Salomo (Kis. 3:11-26). ${ }^{6}$

Selain Petrus, nama lain yang muncul dengan peran cukup penting adalah Yohanes, Stefanus, Filipus, dan Barnabas. ${ }^{7}$ Kehadiran Yohanes lebih banyak ditampilkan dalam menemani Petrus, khususnya dalam percakapan mereka di hadapan Mahkamah Agama (Kis. 4:1-22). Sementara kisah Stephanus ditempatkan sebagai alasan dimulainya penyebaran Injil ke luar Yerusalem, sekaligus sebagai persiapan untuk tampilnya tokoh lain yang bernama Saulus, yang juga disebut Paulus. Akhirnya, sebelum Paulus

\footnotetext{
${ }^{3}$ Köstenberger dan Paterson menambahkannya dengan menekankan misi pekabaran Injil Paulus sebagai penggenapan nubuat nabi Yesaya. Hal ini ditunjukkannya dengan kutipan Yesaya 49:6 dalam Kisah Para Rasul 13:47, dan Yesaya 6:9-10 dalam Kisah Para Rasul 28:26-27. Andreas J. Köstenberger \& Richard D. Patterson, Invitation to Biblical Interpretation: Exploring the Hermeneutical Triad of History, Literature, and Theology (Grand Rapids, MI: Kregel Academic, 2011), 398.

${ }^{4}$ Gooding menuturkan bahwa Kisah Para Rasul sesungguhnya mengungkapkan sebuah pembaruan tatanan masyarakat di dunia dengan kehadiran gereja sebagai tubuh Kristus yang diawali dengan peristiwa pencurahan Roh Kudus di hari Pentakosta. David Gooding, True to the Faith: The Acts of the Apostles: Defining and Defending the Gospel (London: Myrtlefield House, 2013), 38-50.

${ }^{5}$ Macgregor dan Ferris menjelaskan bahwa berdasarkan tata bahasa Yunani, keberadaan rasul-rasul itu lebih dihadirkan sebagai orang-orang yang mendapatkan perintah melalui Roh Kudus. G.H.C. Macgregor \& Theodore P. Ferris, “The Acts of the Apostles", dalam The Interpreter's Bible: A Commentary in Twelve Volumes, Vol.9: Acts \& Rome, peny. Nolan B. Harmon (Nashville, Tennessee: Abingdon, 1982), 25.

${ }^{6}$ Samuel B. Hakh, Perjanjian Baru: Sejarah, Pengantar dan Pokok-pokok Teologisnya (Bandung: Bina Media Informasi, 2010), 298.

${ }^{7}$ Ibid.
} 
ditampilkan sebagai sosok yang benar-benar dominan dalam penuturan Kisah Para Rasul selanjutnya, terdapat Barnabas yang berperan dalam mempersiapkan Paulus untuk mengabarkan Injil di bawah pimpinan Roh Kudus.

\section{Setting Tempat dan Waktu: Antiokhia dan Momentum Konflik}

Setelah melewati kebersamaan yang cukup penting di awal-awal pelayanan Paulus sebagai pekabar Injil, Barnabas akhirnya berpisah dengan Paulus. Kisah Para Rasul 15:3541 berisi laporan tentang bagaimana proses perpisahan mereka. Penuturan kisah perselisihan antara Paulus dan Barnabas diawali dengan keinginan Paulus untuk mengunjungi kembali jemaat di kota-kota yang pernah mereka singgahi sebelumnya, dengan tujuan melihat kondisi jemaat-jemaat di sana (Kis. 15:36). ${ }^{8}$ Keinginan Paulus ini direspons oleh Barnabas dengan mengajak Yohanes yang disebut Markus (Kis. 15:37). Respons Barnabas terhadap rencana Paulus dengan mengajak Yohanes yang disebut Markus ternyata tidak disetujui oleh Paulus. Paulus berkata bahwa tidak baik membawa serta orang yang telah meninggalkan mereka di Pamfilia dan tidak mau turut bekerja bersama-sama dengan mereka (Kis. 15:38). Perbedaan pandangan ini menimbulkan perselisihan tajam di antara keduanya (Kis. 15:39), yang diselesaikan dengan perpisahan arah perjalanan pelayanan mereka. Barnabas bersikeras membawa Yohanes yang disebut Markus berlayar ke Siprus (Kis. 15:39), sedangkan Paulus memilih Silas untuk meneguhkan jemaat-jemaat di Siria dan Kilikia (Kis. 15:40-41).

Sebelum Paulus dan Barnabas berpisah, mereka sempat tinggal beberapa lama di Antiokhia. Penting untuk dicermati bahwa dalam Kisah Para Rasul ada dua kota berbeda yang memiliki nama Antiokhia. Yang pertama adalah Antiokhia di Siria, dan yang kedua adalah Antiokhia di Pisidia. Dengan menelusuri perjalanan Paulus dan Barnabas ke beberapa kota sebelum kembali ke Antiokhia maka dapat disimpulkan bahwa yang dimaksud adalah kota Antiokhia di Siria. Dalam rute perjalanan Paulus dan Barnabas itu dibedakan antara kota yang hanya disebut Antiokhia dengan kota Antiokhia di Pisidia. Artinya, yang dimaksud bukanlah Antiokhia di Pisidia, melainkan yang di Siria.

\footnotetext{
${ }^{8}$ Adam Clarke menjelaskan bahwa keinginan Paulus ini didasari dugaan bahwa orang-orang Kristen yang baru bertobat hasil pekabaran injilnya hidup dalam ketidaksalehan, perselisihan, sibuk dengan berbagai takhayul, serta masuknya orang-orang ke tengah-tengah persekutuan dengan motif hanya mencari keuntungan bagi diri sendiri. Namun demikian kesimpulan ini tidak didukung oleh data dalam Kisah Para Rasul sendiri. Lih. Adam Clarke, The New Testament of Our Lord and Savior Jesus Christ, Vol. I (New York/ Nashville: Abingdon-Cokesbury Press, 1988), 805.
} 
Kota Antiokhia ini dalam Kisah Para Rasul memiliki peran yang sangat penting. Dari sembilan belas kali kota ini disebut dalam Alkitab (di luar Antiokhia di Pisidia), tujuh belas kali terdapat dalam Kisah Para Rasul. Kota ini disebut pertama kali dalam Kisah Para Rasul untuk menjelaskan salah seorang yang dipilih di antara tujuh diaken, yakni Nikolaus (Kis. 6:5). Di situ Nikolaus disebut sebagai seorang penganut agama Yahudi dari Antiokhia. Penyebutan ini memperlihatkan keberadaan Antiokhia yang menjadi tempat hadirnya orang-orang Kristen bukan Yahudi, sekaligus menegaskan gagasan utama Kisah Para Rasul yang ingin menjelaskan bagaimana Injil tersebar dari Yerusalem sampai ke ujung dunia, baik bagi orang-orang Yahudi maupun bukan orang-orang Yahudi.

Selain dikaitkan dengan keberadaan orang-orang Kristen bukan Yahudi, kota Antiokhia juga disebut sebagai tempat Barnabas membawa dan mendampingi Saulus sebelum akhirnya mereka bekerja bersama dalam mewartakan Injil (Kis. 11:25). Saat Paulus dan Barnabas di Antiokhia jugalah untuk pertama kalinya para murid disebut Kristen (Kis. 11:26).

Jika dikaitkan dengan rute perjalanan pekabaran Injil Paulus yang dilaporkan dalam Kisah Para Rasul, kota Antiokhia agaknya dijadikan semacam "home base" oleh Paulus. Dari Antiokhia Paulus memulai perjalanannya yang pertama (Kis. 13:2-14:28), kedua (Kis. 15:35-18:22), dan ketiga sampai akhirnya tiba di kota Roma (Kis. 18:23-28:31). Catatancatatan ini semakin memperlihatkan bagaimana peran Antiokhia yang dihubungkan dengan keberadaan orang-orang Kristen bukan Yahudi menjadi tempat penting bagi misi pekabaran Injil dari Yerusalem sampai ke Roma.

Dengan mencermati pentingnya kota Antiokhia dalam perkembangan pekabaran Injil sebagaimana dituturkan dalam Kisah Para Rasul maka menjadi menarik ketika perselisihan antara Paulus dan Barnabas juga terjadi di tempat itu. Pertanyaannya adalah: adakah hubungan antara perkembangan pekabaran Injil dari Yerusalem dengan perselisihan yang terjadi di antara kedua tokoh tersebut? Untuk menjawabnya maka perlu dicermati latar belakang waktu dari kisah perselisihan tersebut.

Keterangan waktu dalam Kisah Para Rasul 15:35-41 dapat ditelusuri dari rangkaian kisah yang disebutkan sebelumnya yaitu bahwa perselisihan antara Paulus dan Barnabas terjadi setelah mereka selesai melakukan perjalanan dan pelayanan ke beberapa tempat, yakni Seleukia (Kis. 13:4), beberapa tempat di Siprus, yakni Salamis dan Pafos (Kis. 13:56), Perga di Pamfilia (Kis. 13:13), Antiokhia di Pisidia (Kis. 13:14), Ikonium, Listra, dan Derbe (Kis. 13:50-14:20), sebelum akhirnya kembali ke Antiokhia di Siria (Kis. 14:21-28). Dari uraian ini maka dapat disimpulkan bahwa perselisihan antara Paulus dan Barnabas 
terjadi setelah Paulus melakukan perjalanan pelayanan yang pertama, dan dalam persiapan untuk melakukan perjalanan pelayanan berikutnya. ${ }^{9}$ Catatan ini menarik jika dikaitkan dengan tempat perselisihan sebagaimana diuraikan pada bagian sebelumnya, yakni di Antiokhia sebagai tempat yang sangat penting bagi perkembangan pekabaran Injil menurut penuturan Kisah Para Rasul.

Jika dikaitkan dengan seluruh penuturan dalam Kisah Para Rasul maka penempatan waktu perselisihan di dalam persiapan perjalanan pekabaran Injil Paulus yang kedua memperlihatkan bahwa kisah ini memiliki peran penting dan strategis dalam kisah perkembangan pekabaran Injil dari Yerusalem ke Roma. Perselisihan ini dapat dikatakan sebagai peristiwa yang turut menentukan bagaimana Injil tersebar sampai ke ujung dunia melalui apa yang dilakukan oleh Paulus. Kesimpulan ini sesuai dengan pola penuturan dalam Kisah Para Rasul. Dapat dikatakan bahwa setiap fase perkembangan yang menentukan seringkali diisi dengan konflik. Contohnya adalah penganiayaan terhadap jemaat di Yerusalem dalam Kisah Para Rasul 8:1b-3. Konflik tersebut membuat jemaat di Yerusalem tersebar ke seluruh wilayah Yudea dan Samaria. Inilah peristiwa dimulainya fase penyebaran Injil ke luar dari Yerusalem, yakni ke Samaria, hingga ke ujung dunia. Demikian juga dengan kisah selanjutnya, perjalanan Paulus hingga ke Roma dituturkan dalam Kisah Para Rasul sebagai bagian dari perjalanan seorang yang tengah menjalani proses pengadilan. Konflik yang mendera Paulus itulah yang membuatnya sampai ke kota Roma, yang dalam penuturan Kisah Para Rasul adalah ujung dunia.

\section{Dua Model Kepemimpinan dalam Penuturan Tokoh dan Karakter}

Sedikitnya ada empat tokoh yang disebutkan dalam Kisah Para Rasul 15:35-41, yakni Paulus, Barnabas, Yohanes yang disebut juga Markus, Silas, dan banyak orang lain. Dalam kisah ini disebutkan bahwa Paulus dan Barnabas tinggal beberapa lama di Antiokhia. Menarik untuk diperhatikan bagaimana Kisah Para Rasul menyandingkan kedua tokoh tersebut. Sebanyak enam belas kali nama Paulus dan Barnabas disandingkan dengan kata penghubung "dan" (kai). Lima belas kali di antaranya menempatkan Paulus sebelum Barnabas, dan hanya sekali yang sebaliknya, yakni dalam Kisah Para Rasul 14:14. Jika dikaitkan dengan nama Saulus sebelum terbiasa dengan penggunaan nama Paulus dalam penuturan Kisah Para Rasul, nama Barnabas selalu ditempatkan lebih dulu daripada

${ }^{9}$ Lih. William Barclay, The Acts of the Apostles, revised edition (Philadelphia: The Westminster Press, 1976), 118-119. 
Paulus. Ada lima kali keduanya disandingkan dengan kata hubung "dan” (kai), yakni dalam Kisah Para Rasul 11:30, 12:25, 13:2,4,7.

Dalam Kisah Para Rasul 14:14, Barnabas disebut lebih dahulu daripada Paulus ketika merespon orang-orang di Listra yang menganggap Barnabas dan Paulus sebagai para dewa yang menjelma menjadi manusia (Kis. 14:11). Di situ Paulus dianggap sebagai Hermes, sedangkan Barnabas dikira Zeus. Penyebutan Barnabas lebih dulu daripada Paulus mungkin saja berhubungan dengan posisi Zeus dan Hermes dalam mitologi Yunani. Dalam mitologi Yunani, Zeus adalah raja para dewa, sementara Hermes adalah anak dari Zeus dan Maia. ${ }^{10}$ Sebagai anak maka wajar jika posisi Hermes ditempatkan setelah Zeus. Penempatan Barnabas sebelum Paulus agaknya mengikuti tanggapan orang-orang di Listra, termasuk reaksi imam dewa Zeus yang membawa lembu-lembu jantan dan karangankarangan bunga ke pintu gerbang kota untuk dipersembahkan kepada kedua rasul itu (Kis. 14:13). Dengan kata lain, penempatan siapa yang terlebih dahulu di antara Paulus dan Barnabas, yang diikat dengan kata hubung "dan" mengikuti uraian kisah sebelum dan sesudahnya. Kesimpulan ini dipertegas dengan peran Barnabas tatkala mempersiapkan sosok seorang yang bernama Saulus, yang juga disebut Paulus. Peran Barnabas saat itu jauh lebih dominan daripada Saulus. Sebaliknya, ketika nama Paulus lebih awal ditempatkan daripada Barnabas maka Kisah Para Rasul agaknya sedang memperlihatkan peran Paulus yang lebih dominan daripada Barnabas. Hal ini diperkuat dengan peran Paulus yang mendominasi penuturan dalam Kisah Para Rasul selanjutnya.

Walaupun Paulus agaknya mendapat porsi jauh lebih banyak dalam penuturan Kisah Para Rasul, tetapi keduanya disebut tinggal beberapa lama di Antiokhia. Setidaknya ada tiga kali Kisah Para Rasul menjelaskan kebersamaan Paulus dan Barnabas untuk tinggal beberapa waktu di suatu tempat (Kis. 14:3; 15:33; 15:36). Keterangan ini menjelaskan kedekatan mereka berdua, khususnya saat di Antiokhia. Pada bagian sebelumnya, ditunjukkan peran penting Barnabas dalam proses penyiapan Paulus. Dalam Kisah Para Rasul 9:26-27 dituliskan bahwa, "Setibanya di Yerusalem Saulus mencoba menggabungkan diri kepada murid-murid, tetapi semuanya takut kepadanya, karena mereka tidak dapat percaya, bahwa ia juga seorang murid. Tetapi Barnabas menerima dia dan membawanya kepada rasul-rasul dan menceriterakan kepada mereka, bagaimana Saulus melihat Tuhan di tengah jalan dan bahwa Tuhan berbicara dengan dia dan bagaimana keberaniannya mengajar di Damsyik dalam nama Yesus.” Ketika banyak orang

\footnotetext{
${ }^{10}$ E. M. Berens, The Myths \& Legend of Ancient Greece and Rome (Amsterdam: MetaLibri, 2009),
} $17-18,101$. 
menolak kehadiran Paulus, Barnabas mengambil sikap yang berbeda. Ia menerima dan memberikan pembelaan bagi Paulus.

Kebersamaan Paulus dan Barnabas juga ditunjukkan dengan bersama-sama banyak orang lain mengajar dan memberitakan firman Tuhan. Catatan ini memperlihatkan bahwa mereka dapat bekerja sama dengan banyak orang, sekaligus menjelaskan bahwa keberhasilan dalam penyebaran Injil sampai ke ujung dunia tidak bergantung pada satu atau dua orang, tetapi karena kuasa Roh Kudus yang bekerja melalui banyak orang, termasuk Paulus dan Barnabas.

Di antara orang banyak yang turut mewartakan Injil adalah Yohanes yang disebut dengan Markus, dan Silas. Yohanes yang juga disebut Markus pertama kali muncul dalam Kisah Para Rasul 12:12. Ia anak seorang perempuan yang bernama Maria, yang tinggal di Yerusalem. Perempuan itu disebutkan sebagai seorang pemilik rumah yang disinggahi oleh Petrus, yang waktu itu menjadi tempat banyak orang berkumpul dan berdoa. Catatan ini memperlihatkan kualitas keluarga Yohanes yang disebut Markus itu. Ia berasal dari keluarga yang rumahnya dijadikan tempat berkumpul dan berdoa para murid Tuhan. Paulus dan Barnabas kelihatannya membawa Yohanes yang disebut Markus setelah mereka menyelesaikan tugas pelayanan mereka (Kis. 12:25), yakni penyerahan dana hasil pengumpulan jemaat di Antiokhia untuk jemaat di Yerusalem (Kis. 11:30).

Dalam Kisah Para Rasul 15:36-41, kehadiran Yohanes yang disebut juga Markus diceritakan sebagai alasan perselisihan Paulus dan Barnabas. Perselisihan itu bermula dari rencana Paulus yang mengajak Barnabas untuk mengunjungi jemaat-jemaat di kota-kota yang pernah mereka singgahi. Mereka ingin melihat bagaimana kondisi atau keberadaan jemaat-jemaat itu. Untuk menanggapi ajakan sekaligus rencana Paulus ini maka Barnabas berniat mengajak Yohanes yang disebut Markus. Keinginan Barnabas ini ditolak oleh Paulus. Menurutnya, tidak baik membawa Yohanes yang disebut Markus itu karena pernah meninggalkan Paulus dan Barnabas saat di Pamfilia, dan tidak mau bekerja bersama-sama mereka di sana, dan malah kembali ke Yerusalem (Kis. 15:38). Tidak dijelaskan di sana alasan undurnya Yohanes yang disebut Markus itu dari perjalanan bersama Paulus dan Barnabas. Apakah mungkin dia melakukan itu karena takut atau tidak tahan dengan beratnya tantangan ketika mereka mewartakan Injil? Apakah ada alasan lainnya? Kisah Para Rasul tidak menjelaskannya sama sekali. Yang pasti, Paulus menolak keinginan Barnabas dengan alasan sikap dan tindakan yang telah dilakukan oleh Yohanes dan yang disebut juga Markus itu. Penolakan Paulus menimbulkan 'perselisihan yang tajam' dengan Barnabas, dalam bahasa lain 'bertengkar keras' dan menyebabkan keduanya 
berpisah. Kenyataan itu tidak menyurutkan niat Barnabas untuk tetap mengajak YohanesMarkus, mereka berangkat ke Siprus. Paulus lebih memilih Silas sebagai rekan sekerjanya dan keduanya berangkat mengelilingi Siria kemudian Kilikia.

Nama Silas muncul pertama kali dalam Kisah Para Rasul 15:22. Bersama dengan Yudas yang disebut Barsabas, Silas diutus berdasarkan sidang di Yerusalem menemani Paulus dan Barnabas ke Antiokhia dalam rangka menyampaikan keputusan sidang di Yerusalem. Keduanya disebut sebagai orang-orang yang terpandang di antara peserta yang hadir dalam persidangan tersebut (Kis. 15:22). Kata Yunani yang digunakan untuk menyebut orang-orang terpandang adalah hêgoumenous, yang berasal dari kata dasar hêgeomai. Dalam LXX kata hêgoumenous umumnya digunakan untuk menyebut orangorang yang layak memiliki peran sebagai pemimpin berdasarkan kualitas kepribadiannya maupun kepemilikan harta, seperti dalam Ulangan 1:13, Yosua 13:21, dan 2 Tawarikh 5:2. ${ }^{11}$ Kualitas pribadi Silas ini ditegaskan oleh Kisah Para Rasul dengan menyebutnya sebagai seorang nabi bersama dengan Yudas (Kis. 15:32). Selain itu, bersama dengan Paulus, Silas juga memiliki kewarganeragaan Romawi (Kis. 16:38).

Catatan-catatan mengenai kualitas Silas sebagaimana disebutkan di atas terungkap dalam sepak terjangnya bersama dengan Paulus. Dalam perjalanan keliling dari kota ke kota, Paulus dan Silas menyampaikan keputusan-keputusan yang diambil para rasul dan para penatua di Yerusalem dengan pesan, supaya jemaat-jemaat menurutinya (Kis. 16:4). Bersama Paulus, ia juga mengalami tekanan dan hambatan seperti ketika mereka ditangkap dan dimasukkan ke dalam penjara di Filipi (Kis. 16:19-40). Dalam menghadapi tantangan tersebut, Kisah Rasul terkesan memperlihatkan keteguhan mereka berdua, dan bahkan menjadikan peristiwa berat itu sebagai pendukung pewartaan Injil yang mereka lakukan. Ketika berada dalam penjara di Filipi, diceritakan bagaimana Paulus dan Silas berdoa dan menyanyikan puji-pujian kepada Allah, dan orang-orang hukuman lain mendengarkan mereka (Kis. 16:25).

Berangkat dari data kepribadian Silas yang dibuat oleh Kisah Para Rasul, serta sepak terjangnya bersama Paulus maka dapat dimengerti mengapa Paulus mengajak Silas. Pertanyaannya adalah mengapa Barnabas berniat membawa serta Yohanes yang disebut Markus? Bahkan niatnya begitu keras hingga menghasilkan perselisihan yang diselesaikan lewat keputusan berpisah arah perjalanan dengan Paulus. Dari seluruh uraian dalam Kisah

\footnotetext{
${ }^{11}$ Bdk. James Strong, Dictionary of the Greek Testament (Chattanooga: AMG Publishers, 1977), 35. Gerhard Kittel (ed), Theological Dictionary of the New Testament Vol II, terj. Geoffrey W. Bromiley, reprinted (Grand Rapids, MI: Wm. B. Eerdmans Publishing Co., 1982), 907.
} 
Para Rasul, terlihat jelas bagaimana Barnabas dan Paulus memiliki kepribadian yang kuat. Masing-masing memiliki prinsip yang teguh. Bisa jadi keputusan Barnabas untuk membawa serta Yohanes yang disebut Markus sejalan dengan keputusannya ketika menerima dan membela Paulus di hadapan para pengikut Kristus yang tidak dapat mempercayai Paulus berdasarkan masa lalu Paulus. Barnabas dalam hal ini dapat dipandang sebagai sosok yang memiliki sikap layaknya seorang pastor atau gembala yang memberikan kesempatan kembali kepada orang-orang yang mungkin telah jatuh, bahkan meninggalkan Tuhan. Di sisi lain, keputusan Paulus juga dapat dimengerti mengingat tantangan yang begitu berat dalam pekabaran Injil, sehingga dibutuhkan orang-orang yang punya kesiapan lahir batin. Baginya, akan menjadi persoalan seandainya dalam situasi yang berat ada rekan-rekan sekerjanya yang kembali meninggalkannya, hal ini akan menjadi batu sandungan bagi pewartaan Injil yang tengah dijalankannya. Terlepas benar atau tidaknya semua dugaan ini, yang pasti Paulus dan Barnabas berpisah arah perjalanan.

\section{Retorika: Kembali Kepada Keutamaan Karya Roh Kudus}

Kisah Para Rasul 15:36-41 agaknya menampilkan kembali gagasan dari seluruh cerita yang ditampilkan dalam Kisah Para Rasul, yang menggunakan konflik sebagai hal penting dalam proses pewartaan Injil dari Yerusalem sampai ke ujung dunia. Pada bagian awal, terlihat hubungan Barnabas dan Paulus begitu baik dalam bekerjasama, tetapi kemudian mereka berselisih dan berpisah. Dalam setiap konflik yang dikisahkan, selalu ada pesan-pesan atau keputusan-keputusan penting yang mempengaruhi proses pewartaan Injil. Demikian pula dengan perselisihan yang terjadi pada Paulus dan Barnabas. Peristiwa itu tidak sama sekali menghambat pewartaan Injil yang mereka lakukan, sebaliknya dengan mengisahkan adanya perbedaan arah tujuan yang mereka tempuh maka semakin banyak tempat yang mereka jelajahi.

Selain tidak menghambat pekabaran Injil, alasan perbedaan pandangan antara Paulus dan Barnabas juga tidak dijelaskan secara detil selain pernyataan Paulus tentang apa yang pernah dilakukan oleh Yohanes yang disebut Markus. Catatan ini penting mengingat banyak penafsir yang menyebut Yohanes yang disebut Markus itu adalah kemenakan Barnabas. Alasan dari pandangan-pandangan ini adalah catatan dalam Kolose 4:10. ${ }^{12}$ Jika

\footnotetext{
${ }^{12}$ Elsie E. Egermeier, Egermeier's Bible Story Book, story revision by Arlene S. Hall (Indiana: The Warner Press, 1969), 531.; Everett F. Harrison, Acts: The Expanding Church (Chicago: Moody Press, 1975), 242.
} 
benar bahwa alasan Barnabas mengajak Yohanes yang disebut Markus itu adalah karena hubungan keluarga maka wajar jika peristiwa tersebut merupakan sesuatu yang menyedihkan. Namun demikian, Kisah Para Rasul tidak mengungkit itu sama sekali. Kisah Para Rasul lebih tertarik menceritakan bagaimana peran Barnabas sebelumnya dalam mempersiapkan sosok Saulus yang oleh Kisah Para Rasul kemudian disebut Paulus. Dalam penuturan Kisah Para Rasul, alasan Barnabas untuk tetap membawa Yohanes yang disebut Markus sepertinya tidak dianggap penting. Yang penting justru alasan Paulus yang dihubungkan dengan pengalaman dan rencana perjalanan pekabaran Injil berikutnya. Artinya, Kisah Para Rasul lebih ingin menjelaskan bagaimana keberhasilan pekabaran Injil itu ke depan dapat dilakukan oleh Paulus dengan Silas.

Retorika dalam penuturan yang menggunakan konflik sebagai peristiwa yang turut membuat pekabaran Injil semakin berkembang dapat juga dilihat dalam kisah Ananias dan Safira (Kis. 5:1-10). Kisah ini jauh lebih mencerminkan sisi-sisi negatif dalam persekutuan gereja perdana yang seringkali dipandang ideal. Kisah Ananias dan Safira ditutup dengan pernyataan, "Maka sangat ketakutanlah seluruh jemaat dan semua orang yang mendengar hal itu." Di balik pernyataan tersebut terkandung pandangan tentang kuasa Roh Kudus yang tidak dapat dipermainkan oleh manusia. Gagasan tersebut sebenarnya tercermin juga dari kisah perselisihan Paulus dan Barnabas yang secara gamblang memperlihatkan keterbatasan-keterbatasan yang dimiliki oleh orang-orang Kristen dalam persekutuan gereja mula-mula, termasuk para pekabar Injil. Uniknya, keterbatasan-keterbatasan itu tidak menghambat penyebaran Injil, tetapi ditampilkan sebagai yang turut mendukung penyebaran pekabaran Injil. Hal ini terjadi karena pekerjaan Roh Kudus tidak dapat dihambat oleh apapun, termasuk oleh berbagai persoalan yang mendera orang-orang yang diberi kepercayaan untuk mengabarkan Injil.

\section{Kesimpulan}

Dari uraian di atas maka sedikitnya ada tiga kesimpulan. Pertama, Kisah Para Rasul menempatkan perselisihan antara Paulus dan Barnabas bukan sebagai perkara yang buruk. Perselisihan di antara kedua tokoh tersebut ditempatkan sebagai sebuah perbedaan pandangan terkait siapa yang harus mereka ajak dalam menengok jemaat-jemaat yang sudah mereka dirikan. Perbedaan pandangan ini berakhir dengan keputusan masing-masing dalam mengambil arah yang berbeda terkait perjalanan pekabaran Injil. Perbedaan arah 
perjalanan dalam pekabaran Injil yang mereka tempuh dilihat secara positif sebagai sumbangsih dalam memperluas pekabaran Injil.

Kedua, pekabaran Injil yang dilakukan Paulus bisa dikatakan berhasil karena dia didampingi seorang teman seperjalanan yang berkualitas secara personal dan sosial yaitu Silas. Seandainya dalam pelayanannya dia mendapat tantangan dari teman seperjalanan, mungkin situasinya akan berbeda. Sementara itu kita tidak mendapatkan penjelasan yang memadai mengenai kisah perjalanan pekabaran Injil yang dilakukan Barnabas dan Yohanes yang disebut Markus. Tidak ada sedikitpun catatan lainnya, termasuk catatan negatif tentang mereka. Kisah Barnabas dan Yohanes yang disebut Markus berhenti sampai di sini. Sementara Kisah Para Rasul menuturkan berbagai peristiwa yang dilakukan dan dialami Paulus dan Silas di berbagai tempat pekabaran Injil yang dilayani mereka berdua. Tidak ada peristiwa buruk yang terjadi sebagai imbas perselisihan dan keputusan mereka untuk berpisah dan mengambil jalan yang berbeda. Sebaliknya, mereka dapat menjangkau wilayah yang lebih luas dalam melaksanakan pekerjaan Roh Kudus. Agaknya Kisah Para Rasul hendak mengedepankan peran Paulus yang cukup besar dalam pekabaran Injil, namun sekaligus memperlihatkan betapa pentingnya peran teman seperjalanan yang sehati, sepikir dan saling mendukung seperti Silas untuk berhasilnya pekabaran Injil. Selain bahwa memang semua hal terjadi hanya oleh karena peran Roh Kudus dalam diri orang-orang beriman dan dalam segala peristiwa sepanjang perjalanan pelayanan mereka di hadapan Tuhan.

Ketiga, selain tidak ada catatan negatif berkenaan dengan akibat dari keputusan mereka, perselisihan tersebut semakin memperjelas retorika penceritaan yang menempatkan konflik-konflik sebagai bagian penting dalam proses penyebaran Injil yang dilakukan oleh para rasul dalam bimbingan Roh Kudus. Penganiayaan terhadap Stefanus, perilaku buruk Ananias dan Safira, serta perselisihan antara Paulus dan Barnabas dikisahkan sebagai peristiwa-peristiwa penting yang membuat Injil semakin tersebar ke berbagai wilayah, yang dimulai dari Yerusalem sampai ke ujung dunia. Keputusan untuk mengambil jalan yang berbeda justru menjadi pintu yang terbuka bagi penyebaran Injil ke wilayah-wilayah yang lebih luas. Pemahaman ini sebenarnya sudah dinyatakan dalam penuturan Kisah Para Rasul sejak awal. Kepelbagaian bahasa dalam peristiwa pencurahan Roh Kudus di hari Pentakosta memperlihatkan bahwa keragaman merupakan tanda kehadiran Allah yang penuh kuasa.

Berbicara tentang Paulus dan Barnabas juga sama halnya dengan membahas dua orang pemimpin. Keduanya merasa bertanggungjawab untuk mengambil suatu keputusan 
yang diperlukan agar visi dan misi dapat tercapai, dan pekerjaan mereka dapat dipertanggungjawabkan di hadapan Tuhan. Visi mereka berdua agaknya tidak dapat dipisahkan dari visi yang terkandung dalam gagasan penuturan Kisah Para Rasul, yakni injil tersebar dari Yerusalem sampai ke ujung dunia. Sedangkan misi yang mereka emban berdasarkan Kisah Para Rasul 15:35-41 adalah menengok jemaat-jemaat yang pernah mereka bangun sekaligus untuk memberitakan firman di sana.

Keduanya sepakat bahwa untuk mencapai visi dan misi diperlukan sumber daya manusia dengan kualifikasi tertentu, tetapi di sini ketidaksepakatan muncul. Paulus tidak sepakat dengan perekrutan sumber daya manusia sesuai ketentuan kualifikasi yang diusulkan oleh Barnabas. Dasar pertimbangan Paulus adalah pengalaman yang pernah dirasakan ketika bekerjasama dengan yang diusulkan oleh Barnabas. Dia lebih memilih orang lain dengan kualifikasi yang menurutnya akan lebih baik dalam melakukan tugas untuk mencapai visi dan misi mereka. Terjadilah perbedaan pendapat dan perselisihan yang tajam. Pertengkaran keras terjadi sehinggasituasi menjaditidak nyaman. Visi dan misi mereka hampir gagal. Keduanya mengambil keputusan untuk berpisah, karena jika tetap bersama maka visi dan misi mereka tidak akan tercapai. Sebaliknya, perpisahan mendorong keduanya mengambil jalan yang berbeda untuk pekerjaan yang sama; untuk mencapai visi dan misi mereka. Pada akhirnya, diketahui hasil dari perpisahan itu adalah pekerjaan pekabaran Injil semakin luas. Pekerjaan mereka masing-masing dapat dipertanggungjawabkan di hadapan Tuhan.

Seorang pemimpin mempunyai tanggung jawab tetapi sekaligus kerentanan. ${ }^{13}$ Tanggung jawab para pemimpin ditentukan oleh tujuan untuk mencapai visi dan misi mereka. Setiap tanggung jawab selalu disertai kerentanan, yaitu masuk ke dalam berbagai risiko menjadi pemimpin. Risiko untuk masuk dalam relasi kebergantungan satu dengan yang lain, risiko untuk menawarkan diri sendiri dalam melayani visi, misi dan bahkan para pengikut. Risiko itu adalah tingginya kemungkinan untuk gagal dan berada di luar kendali pemimpin. Jika kepemimpinan berarti kerentanan, lalu untuk apa seseorang menerima tanggung jawab menjadi pemimpin? Satu-satunya alasan adalah karena Allah meminta dan menganugerahkan seorang pemimpin suatu anugerah yaitu umat-Nya (Rm. 12). Jika seseorang memimpin karena Allah meminta, ia mempunyai kepercayaan diri bahwa kerentanan seorang pemimpin dibungkus dalam harapan akan adanya pengampunan. Pengampunan inilah yang memampukan seorang pemimpin untuk mengerjakan tanggung

${ }^{13}$ Walter C. Wright, Relational Leadership: A Biblical Model for Leadership Service (Cumbria, UK.: Paternoster Publishing Press, 2001), 185. 
jawab tanpa ada rasa takut untuk gagal dan menyelesaikannya untuk kemudian dipertanggungjawabkan di hadapan Tuhan.

Paulus dan Barnabas mempunyai pengalaman akan pengampunan. Paulus mendapatkan pengampunan dari Tuhan dengan masa lalu yang pahit sebagai seorang penganiaya, ia diubahkan menjadi seorang pemimpin yang membagikan visi dan misi Allah kepada umatNya. Barnabas menjadi saksi bahwa seorang yang bersalah jika diberi dukungan dan kesempatan kedua untuk berbuat sesuatu bagi Tuhan tidak pernah sia-sia. Barnabas adalah saksi kunci yang memberi dukungan dan membela Paulus tatkala ditolak oleh para pemimpin di Yerusalem sehingga Paulus mempunyai kesempatan kedua untuk membuktikan diri dan pertobatannya di hadapan Tuhan. Barnabas berhasil mengerjakan bagiannya. Paulus berhasil membuktikan pertobatan dirinya. Pengalaman terhadap pengampunan ini ternyata melahirkan dua pandangan dalam menyikapi kepemimpinan. Pada akhirnya keduanya berhasil menyelesaikan tugas mereka, tetapi dengan menggeser posisi kepemimpinan menuju arah yang berbeda, meski tidak berlawanan dalam rangka pencapaian visi dan misi. Visi dan misi yang diamanatkan Allah kepada mereka tercapai bahkan melampaui ekspektasi karena dua pemimpin meletakkan kerentanan kepemimpinan mereka di tangan Tuhan.

\section{Kepustakaan}

Barclay, W. The Acts of the Apostles, revised edition. Philadelphia: The Westminster Press, 1976.

Berens, E. M. The Myths \& Legend of Ancient Greece and Rome. Amsterdam: MetaLibri, 2009.

Clarke, A. The New Testament of Our Lord and Savior Jesus Christ, Vol. I. New York/ Nashville: Abingdon-Cokesbury Press, 1988.

Egermeier, Elsie E. Egermeier's Bible Story Book, story revision by Arlene S. Hall, Indiana: The Warner Press, 1969.

Gooding, D. True to the Faith: The Acts of the Apostles: Defining and Defending the Gospel. London: Myrtlefield House, 2013.

Hakh, Samuel B. Perjanjian Baru: Sejarah, Pengantar dan Pokok-pokok Teologisnya. Bandung: Bina Media Informasi, 2010.

Harrison, E. F. Acts: The Expanding Church. Chicago: Moody Press, 1975.

Kittel, G (ed). Theological Dictionary of the New Testament Vol II, terj. Geoffrey W. Bromiley, reprinted, Grand Rapids. Michigan: Wm. B. Eerdmans Publishing Co, 1982. 
Köstenberger, Andreas J \& Richard D. Patterson. Invitation to Biblical Interpretation: Exploring the Hermeneutical Triad of History, Literature, and Theology. Grand Rapids, MI: Kregel Academic, 2011.

Macgregor, G. H. C \& Theodore P. Ferris. "The Acts of the Apostles", dalam The Interpreter's Bible: A Commentary in Twelve Volumes, Vol.9: Acts \& Rome, peny. Nolan B. Harmon, Nashville. Tennessee: Abingdon, 1982.

Stott, John R. W. The Message of Acts. Leicester: Inter-Varsity Press, 1990.

Strong, J. Dictionary of the Greek Testament. Chattanooga: AMG Publishers, 1977.

Swindoll, Charles R. The Growts of An Expanding Mission: A Study of Acts 10:1-18:18. Anaheim, California: IFL, 1992.

Wright, Walter C. Relational Leadership: A Biblical Model for Leadership Service. Cumbria, UK.: Paternoster Publishing Press, 2001. 